Dept. of Animal Hygiene

Fac. Vet. Med., Assiut University

\title{
FUNGICIDAL EFFECT OF THE COMMON DISINFECTANTS ON THE MOST WIDELY SPREAD DERMATOPHYTES WITH REFERENCES TO THEIR DIFFERENTIAL RESISTANCE “IN-VITRO” STUDY (With 6 Tables)
}

\author{
By \\ S.A SOTOHY and A. A. MOHAMED* \\ *Dept. of Zoonoses, Fac. of Vet. Medicine, Zagazig University.
}

(Received at 11/3/1999)

تأثير بعض المطهرات علي الفطريات الجلديه واسعه الاتتشار : دراسه مقارنه

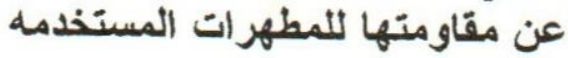

سطوحي أحمد سطوحي ، عمرو عبل ألفتاح محمد

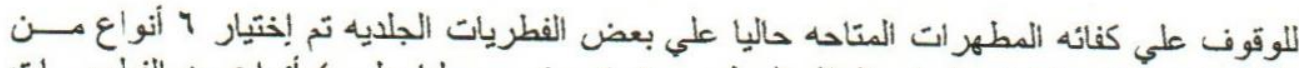

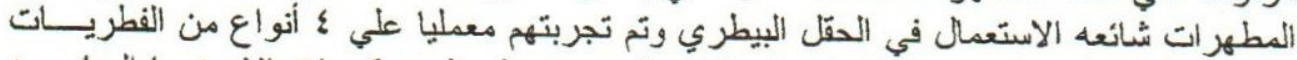

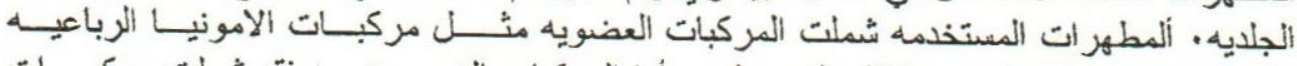

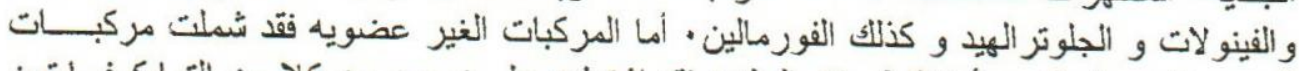

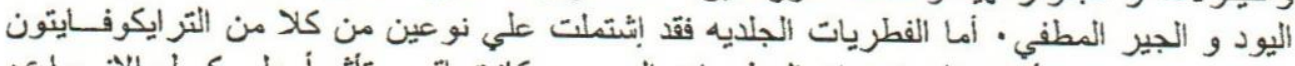

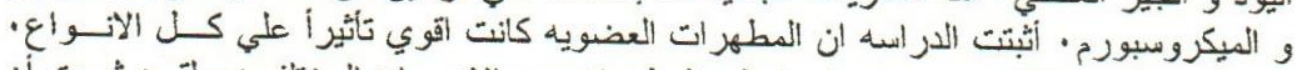

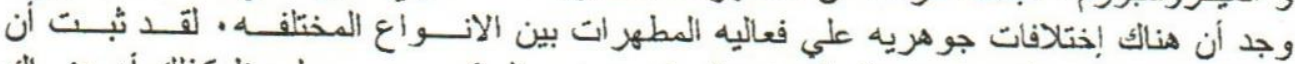

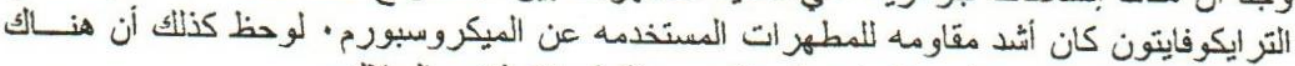
بعض الاختلافات في قابليه الانواع المقار المختلفه من الفطريات لنفس السلاله .

\section{SUMMARY}

In order to control ringworm infection among animals and man, six chemical compounds covering a wide range of the common disinfectants available in the veterinary fields were evaluated against four strains of dermatophytes including T. mentagrophytes, T. rubrum, M. gypsum, and $M$. canis. It was clearly demonstrated that the organic disinfectants are more effective fungicidal than the inorganic ones. There are some qualitative 
differences in the resistance of Trichophyton and Microsporum species to the used disinfectants. However, Trichophyton species show higher resistance to most used disinfectants than Microsporum species. Moreover, within the same fungal species there are some differences in their susceptibility to the same disinfectant. T. rubrum showed a higher resistance than that of $T$. mentagrophytes. Furthermore, $M$. canis showed a higher resistance than $M$. gypsum. The hygienic significance of the fungal species and the fungicidal properties of the disinfectant under test were briefly discussed.

Key words: Dermatophytes, Disinfection, Microsporum, Trichophyton resistance.

\section{INTRODUCTION}

The recent expansion in use of intensive systems of husbandry for rearing of growing stock and management of the adult, increase the problem of controlling spread of the diseases. A comprehensive sanitation program is a key for achieving effective disease control.

Over a period of many years, disinfection was the subject of extensive studies to prevent or at least decrease transmission of the diseaseproducing agents. There is an abundance of literature reporting the studying of the common used disinfectants against certain types of bacteria or fungi (Woodward et al., 1933; Lawrence, 1950; Klarmann and Wright, 1954; Spaudling, 1961; Moustafa et al., 1976, and Ismail, 1967).

Disinfection against dermatophytes, has long been tried and considered. The literature includes a lot of disinfecting agents that had been tried and proved to have significant germicidal action against dermatophytes. Many of the previous trials were conducted upon a single type of the microorganisms or the disinfectant (Woodward et al., 1933; Weirich and Pokorny, 1942; Emmons, 1945; Klarmann and Wright, 1954, Fishman et al., 1966). Differential resistance of the pathogenic fungi against certain types of disinfectant had been worked up instantaneously.

Trichophyton, Microsporum species and other keratinophilic fungi are widely distributed in nature. The soil is considered the most common important reservoir (Ajello et al., 1965; Abd-Elkarim, 1968, and AbouGabal and Abd-Elraheim, 1973). They able to invade and maintain themselves in the keratinized tissues (hair, nails, feathers and horns), inducing dermatophytosis due to their ability to secrete keratinase enzyme that degrade keratin (Tortora et al., 1992). However, the stratum corneum, 
the outermost layer of the skin is the suitable and favorable medium for the growth of these fungi. Dermatophytosis is collectively known as tinea or ringworm, is one of the most common infectious and zoonotic diseases in man and animals. Microsporum species was incriminated in mycotic infections in rabbits (Dvorak and Otcenasek, 1954); dogs (Fishman et al., 1966); horses (Peptin and Austwick, 1968), and cattle (Gupta et al., 1970). On the other hand, Trichophyton species was recorded to be the causative agent in many cases of fungal infections in man and animals. Trichophyton was isolated from dogs (George et al., 1957); sheep (Sharapov, 1962); horses (Cottellar and Christiane, 1967); goats (Peptin and Austwick, 1968); cattle (Mantovani and Morganit, 1971), and rabbits (Evolceanu and Alteras, 1971). Moreover, Trichophyton mentagrophytes was isolated from mycotic affections from man and cattle in Egypt (Abd-Elnoor, 1973).

The importance of animals as reservoirs for many dermatophytes was not fully appreciated. In the late 1950's Lucille George surprisingly determined their significant role in transmitting many members of zoophilic fungi to human beings (El-Mazny et al., 1972; Reddy et al., 1977; ElSamalouty, 1979; McAleer, 1980; Sinski and Kelly, 1987; Hayashi, 1993, and Khosravi et al., 1994). In human beings, dermatophytes produce a wide variety of clinical syndromes including tinea capitis (ringworm of the head); tinea favosa (favus); tinea corporis (body); tinea cruris (groin or jock itch), tinea pedis (athlete's foot), and tinea unguium in the nails (Tortora et al., 1992).

In view of the above consideration, the present work was carried out. A variety of disinfectants commonly used in the veterinary practice were tested "in-vitro" against the most widely spread dermatophytes incriminated in dermatophytosis in man and animals including Trichophyton and Microsporum species. The aim of this work is to find out to what extent each disinfectant can be depend upon in destruction of fungi contaminating animal and poultry enclosures.

\section{Fungal strains:}

\section{MATERIALS and METHODS}

1- Trichophyton mentagrophyte (P 179/96).

2- Trichophyton rubrum (P 345/95).

3- Microsporum canis (P 584/95).

4-Microsporum gypsum (P 563/94). 
These fungal strains were provided by Prof. Dr. Wolfgang Mueller, Institute of Animal and Environmental Hygiene, Free University, Berlin, Germany.

\section{Fungal suspension:}

The fungal spores of the respective fungus were harvested from Sabroud dextrose agar culture and transferred to $20 \mathrm{ml}$ sterile saline (in 100 $\mathrm{ml}$ capacity flask). Sterile glass beads were added and the bottle was placed on a shaker for uniform distribution of the spores in the saline.

\section{Tested disinfectants:}

A variety of disinfectants were used in our study including:-

1-Tek-Trol: It is a $26 \%$ phenolic compound.

2-Iodine Active Sterilizer: It contains 2,3\% (W/V) active iodine.

3-TH4+: A powerful hydrophilic biocide (Glutaraldehyde) activated by a specific blend of four different lipophilic biocides (DDMA, ADMBAC, ODDMAC, DODMAC). Plant extracts (Pine oil, terpineol) improve the remanence and convey a pleasant fragrance).

\section{Composition}

Each 1 iter contains:

Didecyl dimethyl Ammonium Chloride

$18.75 \mathrm{~g}$

Dioctyldimethyl Ammonium Chloride

Octyldecyldimethyl Ammonium Chloride

Alkyldimethyl Benzyl Ammonium Chloride

$18.75 \mathrm{~g}$

$37.50 \mathrm{~g}$

Glutaraldehyde

$50 \mathrm{~g}$

Pine oil

$62.50 \mathrm{~g}$

Terpineol

$20 \mathrm{~g}$

$20 \mathrm{~g}$

4-Quaternary Active Sterilizer: Double component system of quaternary ammonium compounds.

5-Formaline: Different concentrations were prepared, $0.5 ; 1 ; 2$, and $4 \%$ 6-Slaked lime (Calcium hydroxide):

a- Milk of lime was prepared by adding one part of freshly slaked lime to four parts of water $(20 \%)$.

b- Lime wash was prepared by mixing thoroughly one part of milk of lime with nine parts of water $(2 \%)$.

Sterile distilled water was used for preparation of the different dilution of the disinfectants. However, the fungicidal effect of each disinfectant against each of the previously mentioned fungal strains was studied "in vitro" as following:-

- $1 \mathrm{ml}$ of the fungal suspension was added to each dilution of a disinfectant. 
- At time interval up to 2 hours, $0.1 \mathrm{ml}$ from each dilution was streaked on Sabroud agar plate.

- The plates were incubated at $27{ }^{\circ} \mathrm{C}$ for 48 hours, after which plates showed evidence of growth were recorded, while the plates in which no growth were re-incubated again for up to 15 days before their condemnation.

- As control, the original fungal suspension was counted by the pour plate technique (Cruickshank et al., 1980).

- The time at which the organism died was recorded from the plates showed no evidence of growth.

\section{RESULTS and DISCUSSION}

Table 1: Effect of different disinfectants on T. rubrum.

\begin{tabular}{|c|c|c|c|c|c|c|c|}
\hline \multirow[t]{2}{*}{ Disinfectant } & \multirow[t]{2}{*}{ Dilution } & \multirow{2}{*}{$\begin{array}{c}\text { Con. } \\
\%\end{array}$} & \multicolumn{5}{|c|}{ Time of examination } \\
\hline & & & 15 & 30 & 60 & 90 & 120 \\
\hline \multirow[t]{4}{*}{ QAS } & $1: 200$ & $0.5 \%$ & - & - & - & - & - \\
\hline & $1: 400$ & $0.25 \%$ & - & - & - & - & - \\
\hline & $1.500 \%$ & $0.2 \%$ : & 1. & 8 & ?. & 2. & . \\
\hline & $1: 1000$ & $0.1 \%$ & + & + & + & + & + \\
\hline \multirow[t]{4}{*}{ TH4+ } & $1: 50$ & $2 \%$ & - & - & - & - & - \\
\hline & $1: 100$ & $1 \%$ & - & - & - & - & - \\
\hline & $1200^{*}$ & $0.5 \%$ & + & + & - & - & 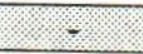 \\
\hline & $1: 400$ & $0.25 \%$ & + & + & + & + & + \\
\hline \multirow[t]{4}{*}{ IAS } & $1: 25$ & $4 \%$ & - & - & - & - & - \\
\hline & 1.50 & $2 \%$ & + & + & + & + & - \\
\hline & $1: 200$ & $0.5 \%$ & + & + & + & + & + \\
\hline & $1: 300^{*}$ & $0.3 \%$ & + & + & + & + & + \\
\hline \multirow{4}{*}{ Tek-Trol } & $1: 100$ & $1 \%$ & - & - & - & - & - \\
\hline & $1: 250^{*}$ & $0.4 \%$ & - & - & - & - & - \\
\hline & 1500 & $0.2 \%$ & +1 & 4 & 4. & $=$ & : \\
\hline & $1: 1000$ & $0.1 \%$ & + & + & + & + & + \\
\hline \multirow[t]{4}{*}{ Formalin } & $4 \%$ & $4 \%$ & - & - & - & - & - \\
\hline & $2 \%$ & $2 \%$ & 1 & t. & . & 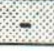 & , \\
\hline & $1 \%$ & $1 \%$ & + & + & + & + & + \\
\hline & $0.5 \%$ & $0.5 \%$ & + & + & + & + & + \\
\hline \multirow[t]{2}{*}{ Slaked lime } & $20 \%$ & $20 \%$ & + & + & + & + & + \\
\hline & $2 \%$ & $2 \%$ & + & + & + & + & + \\
\hline Control & & & $6.3 \times 10^{8}$ & & & & $6.2 \times 10^{8}$ \\
\hline
\end{tabular}

* Recommended concentration by the producer. QAS, Quatemary active sterilizer; IAS, Iodine active sterilizer, con., concentration. 
Table 2: effect of different disinfectants on T. Mentagrophyte.

\begin{tabular}{|c|c|c|c|c|c|c|c|}
\hline \multirow[t]{2}{*}{ Disinfectant } & \multirow[t]{2}{*}{ Dilution } & \multirow{2}{*}{$\begin{array}{c}\text { Con. } \\
\%\end{array}$} & \multicolumn{5}{|c|}{ Time of examination } \\
\hline & & & 15 & 30 & 60 & 90 & 120 \\
\hline \multirow[t]{4}{*}{ QAS } & $1: 200$ & $0.5 \%$ & & - & - & - & - \\
\hline & $1: 400$ & $0.25 \%$ & - & - & - & - & - \\
\hline & $1.500^{*}$ & $0.2 \%$ & 1) & ; & ; & - & 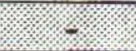 \\
\hline & $1: 1000$ & $0.1 \%$ & + & + & + & + & + \\
\hline \multirow[t]{4}{*}{ TH4+ } & $1: 50$ & $2 \%$ & - & - & - & - & - \\
\hline & $1: 100$ & $1 \%$ & - & - & - & - & - \\
\hline & $1200^{*}$ & $0.5 \%$ & 4 & +1 & 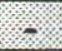 & 留 & 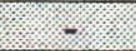 \\
\hline & $1: 400$ & $0.25 \%$ & + & + & + & + & + \\
\hline \multirow[t]{4}{*}{ IAS } & $1: 25$ & $4 \%$ & - & - & - & - & - \\
\hline & 1.50 & $2 \%$ & t & + & 4. & . & 8. \\
\hline & $1: 200$ & $0.5 \%$ & + & + & + & + & + \\
\hline & $1: 300^{*}$ & $0.3 \%$ & + & + & + & + & + \\
\hline \multirow[t]{4}{*}{ Tek-Trol } & $1: 100$ & $1 \%$ & - & - & - & - & - \\
\hline & $1: 250^{*}$ & $0.4 \%$ & - & - & - & - & - \\
\hline & 1.500 & $0.2 \%$ & + & - & - & - & - \\
\hline & $1: 1000$ & $0.1 \%$ & + & + & + & + & + \\
\hline \multirow[t]{4}{*}{ Formalin } & $4 \%$ & $4 \%$ & - & - & - & - & - \\
\hline & $2 \%$ & $2 \%$ & + & - & - & -3 & - \\
\hline & $1 \%$ & $1 \%$ & + & + & + & + & + \\
\hline & $0.5 \%$ & $0.5 \%$ & + & + & + & + & + \\
\hline \multirow[t]{2}{*}{ Slaked lime } & $20 \%$ & $20 \%$ & + & + & + & + & + \\
\hline & $2 \%$ & $2 \%$ & + & + & + & + & + \\
\hline Control & & & $2.4 \times 10^{6}$ & & & & $1.8 \times 10^{6}$ \\
\hline
\end{tabular}

* Recommended concentration by the producer; QAS, Quaternary active sterilizer, IAS, Iodine active sterilizer; Conc, Concentration. 
Table 3: Effect of different disinfectants on M. canis.

\begin{tabular}{|c|c|c|c|c|c|c|c|}
\hline \multirow{2}{*}{$\begin{array}{l}\text { Disin- } \\
\text { fectant }\end{array}$} & \multirow[b]{2}{*}{ Dilution } & \multirow{2}{*}{$\begin{array}{l}\text { Concent- } \\
\text { ration } \%\end{array}$} & \multicolumn{5}{|c|}{ Time of examination } \\
\hline & & & 15 & 30 & 60 & 90 & 120 \\
\hline \multirow{4}{*}{ QAS } & $1: 200$ & $0.5 \%$ & - & - & - & - & - \\
\hline & $1: 400$ & $0.25 \%$ & - & - & - & - & - \\
\hline & $1.500 \%$ & $0.2 \%$ & + & 8 & - & . & 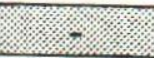 \\
\hline & $1: 1000$ & $0.1 \%$ & + & + & + & + & + \\
\hline \multirow[t]{4}{*}{ TH4+ } & $1: 50$ & $2 \%$ & - & - & - & - & - \\
\hline & $1: 100$ & $1 \%$ & - & - & - & - & - \\
\hline & $1200^{*}$ & $0.5 \%$ & + & 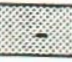 & - & -1 & $=$ \\
\hline & $1: 400$ & $0.25 \%$ & + & + & + & + & + \\
\hline \multirow[t]{4}{*}{ IAS } & $1: 25$ & $4 \%$ & - & - & - & - & - \\
\hline & 1.50 & $2 \%$ & + & + & + & 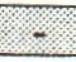 & 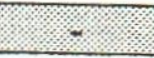 \\
\hline & $1: 200$ & $0.5 \%$ & + & + & + & + & + \\
\hline & $1: 300^{*}$ & $0.3 \%$ & + & + & + & + & + \\
\hline \multirow[t]{4}{*}{ Tek-Trol } & $1: 100$ & $1 \%$ & - & - & - & - & - \\
\hline & $1: 250^{*}$ & $0.4 \%$ & - & - & - & - & - \\
\hline & 1.500 & $0.2 \%$ & + & - & $=$ & - & - \\
\hline & $1: 1000$ & $0.1 \%$ & + & + & - & - & - \\
\hline \multirow[t]{4}{*}{ Formalin } & $4 \%$ & $4 \%$ & - & - & - & - & - \\
\hline & $2 \%$ & $2 \%$ & - & - & - & - & - \\
\hline & $1 \%$ & $1 \%$ & : & s. & - & 4. & 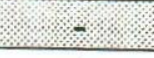 \\
\hline & $0.5 \%$ & $0.5 \%$ & + & + & + & + & + \\
\hline \multirow{2}{*}{$\begin{array}{l}\text { Slaked } \\
\text { lime }\end{array}$} & $20 \%$ & $20 \%$ & + & t. & 1 & -3 & 1. \\
\hline & $2 \%$ & $2 \%$ & + & + & + & + & + \\
\hline Control & & & $4.1 \times 10^{6}$ & 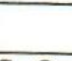 & & 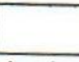 & $3.8 \times 10^{6}$ \\
\hline
\end{tabular}


Table 4: Effect of different disinfectants on M. gypsum.

\begin{tabular}{|c|c|c|c|c|c|c|c|}
\hline \multirow{2}{*}{$\begin{array}{l}\text { Disin- } \\
\text { fectant }\end{array}$} & \multirow{2}{*}{$\begin{array}{c}\text { Dilutio } \\
\mathrm{n}\end{array}$} & \multirow{2}{*}{$\begin{array}{c}\text { Con } \\
\%\end{array}$} & \multicolumn{5}{|c|}{ Time of examination } \\
\hline & & & 15 & 30 & 60 & 90 & 120 \\
\hline \multirow[t]{4}{*}{ QAS } & $1: 200$ & $0.5 \%$ & - & - & - & - & - \\
\hline & $1: 400$ & $0.25 \%$ & + & - & - & - & - \\
\hline & $1.500 *$ & $0.2 \%$ & 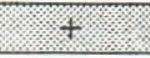 & 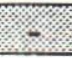 & 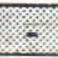 & 3. & s. \\
\hline & $1: 1000$ & $0.1 \%$ & + & + & + & + & + \\
\hline \multirow[t]{4}{*}{ TH4+ } & $1: 50$ & $2 \%$ & - & - & - & - & - \\
\hline & $1: 100$ & $1 \%$ & - & - & - & - & - \\
\hline & $1200^{*}$ & $0.5 \% \%$ & 4. & 8 & $=$ & (x) & 1. \\
\hline & $1: 400$ & $0.25 \%$ & + & + & + & + & + \\
\hline \multirow[t]{4}{*}{ IAS } & $1: 25$ & $4 \%$ & - & - & - & - & - \\
\hline & 1.50 & $2 \%$ & + & 4 & $=$ & - & $=$ \\
\hline & $1: 200$ & $0.5 \%$ & + & + & + & + & + \\
\hline & 1:300* & $0.3 \%$ & + & + & + & + & + \\
\hline \multirow[t]{4}{*}{ Tek-Trol } & $1: 100$ & $1 \%$ & - & - & - & - & - \\
\hline & $1: 250^{*}$ & $0.4 \%$ & - & - & - & - & - \\
\hline & $1: 500$ & $0.2 \%$ & - & - & - & - & - \\
\hline & 1.1000 & $0.1 \%$ & + & + & - & - & - \\
\hline \multirow[t]{4}{*}{ Formalin } & $4 \%$ & $4 \%$ & - & - & - & - & - \\
\hline & $2 \%$ & $2 \%$ & - & - & - & - & - \\
\hline & $1 \%$ & $1 \%$ & - & - & - & - & - \\
\hline & $0.5 \%$ & $0.5 \%$ & + & + & + & + & + \\
\hline \multirow{2}{*}{$\begin{array}{l}\text { Slaked } \\
\text { lime }\end{array}$} & $20 \%$ & $20 \%$ & + & + & + & - & -1 \\
\hline & $2 \%$ & $2 \%$ & + & + & + & + & + \\
\hline Control & & & $5.3 \times 10^{5}$ & & & & $5.0 \times 10^{5}$ \\
\hline
\end{tabular}

* Recommended concentration by the producer; QAS, Quaternary Active sterilizer; IAS, Iodine Active sterilizer; con., concentration. 
Table 5: The minimum lethal dilution of the tested disinfectants on Trichophyton.

\begin{tabular}{|l|c|c|c|}
\hline \multirow{2}{*}{ Disinfectant } & Concent- & \multicolumn{2}{c|}{ Time/min. } \\
\cline { 3 - 4 } & ration \% & T. mentagrophyte & T. rubrum \\
\hline Quaternary Active Sterilizer & $0.2 \%$ & 30 & 90 \\
\hline TH4+ & $0.5 \%$ & 60 & 60 \\
\hline Iodine Active Sterilizer & $2 \%$ & 60 & 120 \\
\hline Tek-Trol & $0.2 \%$ & 30 & 60 \\
\hline Formaline & $2 \%$ & 30 & 60 \\
\hline Slaked lime & $20 \%$ & $\mathrm{NE}$ & $\mathrm{NE}$ \\
\hline
\end{tabular}

NE, No effect

Table 6: Minimum lethal dilution of the tested disinfectants on Microsporum.

\begin{tabular}{|l|c|c|c|c|}
\hline \multirow{2}{*}{ Disinfectant } & \multicolumn{2}{|c|}{$M$. gypsum } & \multicolumn{2}{c|}{ M. canis } \\
\cline { 2 - 5 } & $\begin{array}{l}\text { Concent- } \\
\text { ration } \%\end{array}$ & Time/min. & Concentration $\%$ & Time/min. \\
\hline QAS & $0.2 \%$ & 30 & $0.2 \%$ & 30 \\
\hline TH4+ & $0.5 \%$ & 30 & $0.5 \%$ & 30 \\
\hline IAS & $2.0 \%$ & 60 & $2.0 \%$ & 90 \\
\hline Tek-Trol & $0.1 \%$ & 15 & $0.2 \%$ & 30 \\
\hline Formaline & $1.0 \%$ & 15 & $1.0 \%$ & 15 \\
\hline Slaked lime & $20 \%$ & 90 & $20 \%$ & 90 \\
\hline
\end{tabular}

QAS, Quaternary Active Sterilizer, IAS, Iodine Active Sterilizer.

\section{DISCUSSION}

Various compounds were used in our study covering a wide range of the common disinfectants including phenols, quaternary ammonium compounds, formaline, glutaraldhyde as well as inorganic compounds as iodine and slaked lime.

The obtained results of our investigation revealed that, the organic compounds have a strong antifungal effect than that of the inorganic ones (Tables, 1-4).

Data presented in Tables (1-4) demonstrated that the Tek-Trol which in a phenolic compound posses a powerful antifungal effect on all tested 
species. However, $0.2 \%$ concentration of this compound was much more satisfactory for destruction of mycotic affection caused by dermatophytes. These results are in consistant with results of Moustafa et al. (1976) who found that destruction of $T$. mentagrophytes required as high as $0.5 \%$ of phenolic compounds. On the other hand, these results are supported the work of Woodward et al. (1933) and Klamrann \& Wright (1954). It was stated that phenolic compounds lead to extrusion of cell contents through damaging the cell membranes (Sainsbury and Sainsbury, 1982). Moreover, they act, as protein denaturants as it absorbed to the protein phase, yielding a complex, which may ultimately, be coagulated.

The quaternary ammonium compounds and gltaraldhyde are widely used in the veterinary practice. They are strong disinfectant, safe, nonirritant, and not affected by the organic matter. Data presented in tables 1-4, showed that as low concentration as $0.2 \%$ is quite enough to destroy the fungal spores. However, the quaternary active sterilizer as a quaternary ammonium compound induce this effect within 30 minutes for all fungal species except for $T$. rubrum which require 90 minutes for complete destruction. Moreover, TH4+ which contains quaternary ammonium compounds and glutaraldhyde revealed also strong antifungal effect at $0.5 \%$ within 60 minutes. These results are quietly differ than that obtained by Moustafa et al. (1976) where as higher concentration as $1 \%$ is required to destroy T.mentagrophytes within $150 \mathrm{~min}$. to 2.30 hours. On the other hand these results are quite similar to those obtained by Lawrence (1950). It was stated that the biocidal activity of glutaraldehyde depends on either the availability of two free aldhyde groups in the molecule which react with the amino groups of the cell (Rubbo et $\underline{\text { al., }}$ 1967) or the rapid and complete inhibition of DNA and RNA synthesis (McGucken \& Boodside., 1973). On the other hand, the quaternary ammonium compounds produced intracellular changes after short periods of contact involving cytolytic damage resulting in leakage of the cell constituents into the suspending fluid (Cox, 1995, and Sainsbury and Sainsbury, 1982). These compounds are of high surface activity which are cationic by nature. With their surface absorption the material is brought into more effective contact with the bacterial cell and consequently there is an increase in local concentration around the cell (Hoogerheid, 1945). When dissolved in the water, these compounds are spit into ions that adhere to the surface, giving a long-lasting residual effect.

It was revealed that Microsporum species are much sensitive to formaline than Trichophyton species. However, Tables 1-4, illustrated that $1 \%$ formaline was sufficient to destroy Microsporum species while $2 \%$ was 
required to do the same effect on Trichophyton species. These results are disagreement with that obtained by Moustafa et al. (1976) where as high as $3 \%$ concentration of formaline was required to destroy both Microsporum and Trichophyton.

Concerning the antifungal effect of the inorganic compounds, Tables $1-4$, revealed that they are less effective than organic compounds. Iodine compound must be used at high concentration $(2 \%)$ to destroy both Trichophyton and Microsporum within $120 \mathrm{~min}$. However, iodine reacts with the organism by oxidation-reduction process, but halogenation also takes place (Sainsbury and Sainsbury, 1982).

On the other hand, the freshly slaked lime shows negligible effect. At $20 \%$ concentration, slaked lime required 90 minutes for destroying both Microsporum canis and M. gypsum, while no effect was recorded on Trichphyton species. However, $2 \%$ slaked lime was failed to show any antifungal properties. These results are much similar to those recorded by Moustafa et al. (1976). However, Ismail (1967) concluded that using of the lime wash instead of water for preparation of disinfectants will assure many benefits in the control practice, while the best disinfectant for bedding and earth floor was found to be milk of lime.

The obtained results revealed that there are some qualitative differences between the resistance of Trichophytom and Microsporum species to the used disinfectants. Data presented in Tables $(5,6)$, indicated that Trichophyton species are much resistant to most disinfectants than Microsporum. However, phenolic compound (Tek-Trol) was destroyed Microsporum species within 30 minutes at $0.2 \%$, while the same concentration required 60 minutes to destroy Trichophyton species (Table 5 \& 6). A similar result was obtained by quaternary ammonium compounds where $\mathrm{TH} 4+(0.5 \%)$ and quaternary active sterilizer $(0.2 \%)$ showed faster drastic effect on Microsporum species than Trichophyton species. The last two compounds were required 30 minutes to kill the Microsporum species at the recommended concentration, while they need up to 90 minutes to kill Trichophyton species at the same concentration. Moreover, similar results were recorded by all used disinfectants including iodine compound and formaline (Tables $5 \& 6$ ). Iodine compound required 2 hours to destroy Trichophyton species at $2 \%$ while it only needs one hour to destroy Microsporum at the same concentration. On the other hand, $1 \%$ formaline was sufficient to kill Microsporum species within 15 minutes while Trichophyton species were required $2 \%$ to be destroyed in a longer period (Tables 5 \& 6). Moreover, $20 \%$ freshly slaked lime was effective against 
Microsporum species while it failed to destroy Trichophyton species over two hours. These results agree with those found by Weirch and Pokorny (1942); Spaudling (1961), and Moustafa et al. (1976).

There is no doubt that there are some qualitative differences within the same fungal species. Microsporum gypsum was much susceptible to the used disinfectant than $M$. canis. However, $M$. gypsum was completely destroyed by Tek-Trol after 15 minutes at $0.1 \%$, while a higher concentration $(0.2 \%)$ and longer time was required to destroy $M$. canis.. Moreover, Trichophyton rubrum was more resistant than T. mentagrophytes. It was revealed that most of the used disinfectants were required a longer time to destroy $T$. rubrum than the time required for $T$. mentagrophytes. There is no available literature about the resistant differences between the different fungal strains of the same fungal species.

From the obtained results one can safely concluded that, Trichophyton species are more resistant to most of the disinfectants than Microsporum. Moreover, within the same fungal species there are some qualitative differences between their strains. However, T. rubrum is more resistant than $T$. mentagrophytes. On the other hand, $M$. canis is more resistant to the disinfectants than $M$. gypsum. The organic disinfectants are strong antifungal agents than the inorganic ones. Controlling of the mycotic infections seem possible by using strict hygienic measures to prevent spreading of skin disease as well as comprehensive sanitation program.

\section{REFERENCES}

Abd-El Karim, M. (1968): The incidence of animal infections in the soil of some animal dwellings. M.D. thesis, Fac. of Vet. Med., Cairo Univ., Egypt.

Abd-Elnoor, E. (1973): Studies on ringworm disease among Egyptian farm animals in Upper Egypt. M.Sc. thesis, Fac. of Vet. Med., Assiut Univ., Egypt

Abou-Gabal, M., and Abd-Elrahiem, D. (1973): Ecological investigation on dermatophytes in Upper Egypt. Castellania, 1: 169-174.

Ajello, L.; Varsavsky, E. and Delvingt, W. (1965): Keratinophillic fungi from Belgian soils. Trans. Brit. Mycol. Soc., 48: 417-423.

Cottelar, L. and Christiane, M. (1967): Historical review and incidence of ringworm in animals principally in Belgium. Acta-Zool. Path. Anteverp., 44: 141-145. 
Cox, W.A. (1995): Site of action of certain antibacterial heterocyclic quaternary ammonium compounds. Appl. Microbiol., 13 (6): 956966.

Cruickshank, R.; Dugid, I.P.; Mormion, B.P. and Swain, R.H. (1980): Medical Microbiology, $12^{\text {th }}$ ed., Vol. 11, reprinted Churchill Livingstone and Robert Stevenson, Edinburg, EHI 3, HF.

Dvorak, J. and Otcenasek, M. (1954): Geophillic, anthrophilic and zoophilic dermatophytes. Mycopath. Mycol. Appl., 23: 294-301.

El-Mazny, H.; Abdel-Fattah, A.; Abdallah, M.A. and Rifai, M. (1972): Study of tinea cruris in Egypt. Mckosen, 15: 331-337.

El-Samalouty, M.M. (1979): Clinical and mycological study of tinea corporis in Assiut (Upper Egypt). M.Sc. thesis, Dept. of dermatology, Fac. of Med., Assiut University.

Emmons, C.W. (1945): Proposed method for testing fungicides against Trichophyton. Am.J. public Health, 35: 844-849.

Evolceanu, R. and Alteras, I. (1971): A short review on dermatophytes of soil and animals in Romania. Mycopath. Mycol. Appl., 43: 17-21.

Fishman, A.; Landero, T. and Santiago, M. (1966): Ringworm my M. gypseum in a dog. Mycopath. Mycol. Appl., 30: 19-24.

George, L.; Robert, C.; Menges, R. and Kaplan, W. (1957): T. mentagrophytes infection in dogs and cats. JAVMA, 130: 427-431.

Gupta, K.; Singh, R. and Singh, I. (1970): A study of dermatophytes in domestic animals and fowls. Indian J. Animal Health, 2: 85-91.

Hayashi, N.(1993): Tinea pedis. Asian Med. J., 36 (5); 273-276.

Hoogerheide, J.C. (1945): The germicidal properties of certain quaternary ammonium salts with special refernce to cetyl-trimethyl ammonium bromide. J. Bact., 49: 277-281.

Ismail, A.A. (1967): A comparative study of the chemical disinfectants used in Egyptian Vet. Practice. M.D. thesis, Fac. Vet. Med., Assiut Univ., Egypt.

Khosravi, A.R.; Aghamirian, M.R. and Mahmoud, M. (1994):

Dermatophytosis in Iran. Mycoses, 37 (1/2): 43-48.

Klarmann, E.G. and Wright, E.S. (1954): Phenolic compounds: In: Antiseptics, disinfectants, fungicides and chemical sterilization. Pp. 506, $2^{\text {nd }}$ Ed. (George, F.R.; Lea and Febiger, Pheladelphia.

Lawrence, C.A. (1950): Surface-active quaternary ammonium germicides.

New York, Academic press, Inc., p. 95. 
Lucille George (1950): Quoted by smith, J.M.B.; Aho, R.; Mattsson, R., and Pier, A.C. (1992): Progress in Vet. Mycology. J.Med. \& Vet. Mycol., 30 (1): 307-316.

McAleer, R. (1980): Fungal infections of the scalp in Western Australia. Sabouraudia, 18 (3): 185-190.

Mantovani, A. and Morganit, L. (1971): Research on dermatophytes of mammals in Italy. Vet. Italian, 22: 460-464.

McGucken, P.V. and Boodside, W. (1973): Studies on the mode of action of glutazaldhyde on E. coli. J. Appl. Bact., 36: 419-426.

Moustafa, T.H; Abou-Gabal, M.; Enab, S.A. and Sarhan, A. (1976):

Fungicidal action of some common disinfectants on two dermatophytes (T. mentagrophytes \& M. gypseum. Assiut Vet. Med.

J., 3 (5): 70-77.

Peptin, G. and Austwick, L. (1968): Skin diseases of domestic animals. IISkin diseases of mycological origin. Vet. Res., 82: 208-213.

Reedy, B.S.N.; Singh, G. and Sharama, B.M. (1977): Onychomycosis and nail dystrophy. Int. J. Dermatolo., 23 (1): 1-4.

Rubbo, S.D.; Gardner, J.F. and Webb, R.L. (1967): Biocidal activities of glutaraldhyde and related compounds. J. Appl. Bact., 30 (1): 78-87.

Sainsbury, D. and Sainsbury, P. (1982): Livestock health and housing, pp. 84-109. Butler \& Tannet Ltd, Frome and London.

Sharapov, V. (1962): Prophylaxis against T. mentagrophytes in sheep. Veterinaria, 39: 31-36.

Sinski, J.T. and Kelly, L. (1987): A survey of dermatophytes isolated from human patients in the United stated from 1982-1984. Mycopathol., 89: 35-40.

Spaudling, E.H. (1961): Chemical disinfection of medical and surgical materials. In: In: Antiseptics, disinfectants, fungicides and chemical sterilization. pp. 619, $2^{\text {nd }}$ Ed. (George, F.R.; Lea and Febiger, Pheladelphia.

Tortora, G.J; Funke, B.R. and Case, C.L. (1992): Microbiology. An Introduction. $4^{\text {th }}$ Ed., The Benjamin/Commings Publishing Compant, Inc.

Weirich, C. and Pokorny, R. (1942): Athletes foot control. Soap Sanit. Chemicals, 18 (97): 117-123.

Woodward, G.J.; Kingery, L.B. and Williams, R.J. (1933): The fungicidal power of phenols derivatives. 1- Effect of introducing alkyl groups and halogens. J. Lab. Clin. Med., 19: 1216-1220. 